\title{
Penerapan Model Guided Discovery Learning dalam Mengembangkan Kemampuan Mengkonstruksi Bukti Geometri
}

\author{
Samsul Maarif ${ }^{*}$, Trisna Roy Pradipta ${ }^{2}$, Surya Amami Pramuditya ${ }^{3}$, \\ Muchamad Subali Noto ${ }^{4}$ \\ 1,2Program Studi Pendidikan Matematika, Universitas Muhammadiyah Prof. Dr. HAMKA, \\ Jakarta, Indonesia; ${ }^{*}$ samsul maarif@uhamka.ac.id; ${ }^{2}$ troymath@uhamka.ac.id \\ 3,4Program Studi Pendidikan Matematika, Universitas Swadaya Gunung Djati, Cirebon, \\ Indonesia; ${ }^{4}$ amamisurya@gmail.com; ${ }^{3}$ msubalinoto@fkip-unswagati.ac.id,
}

Info Artikel: Dikirim: 18 November 2019; Direvisi: 3 Februari 2020; Diterima: 10 Maret 2020 Cara sitasi: Maarif, S., Pradipta, T.R., Pramuditya, A. S., \& Noto, M. S. (2020). Penerapan Model Guided Discovery Learning dalam Mengembangkan Kemampuan Mengkonstruksi Bukti Geometri . JNPM (Jurnal Nasional Pendidikan Matematika) 4(2), 28-43.

\begin{abstract}
Abstrak. Penelitian ini bertujuan untuk menganalisis penerapan model Guided Discovery Learning (GDL) dalam meningkatkan kemampuan mengkonstruksi bukti geometri $(K M B G)$ pada perkuliahan geometri dasar. Penelitian menggunakan eksperimen factorial design $3 \times 2$ yang melibatkan dua kelas geomeri dasar dengan perlakuan pembelajaran yang berbeda yakni model GDL di kelas eksperimen dan model Direct Instruction (DI) di kelas kontrol. Populasi pada penelitian ini adalah seluruh mahasiswa yang mengikuti mata kuliah geometri dasar Program Studi Pendidikan Matematika di salah satu Perguruan Tinggi. Sampel penelitian sejumlah 75 mahasiswa dipilih dengan teknik Cluster Random Sampling yang terbagi dalam kelas ekperimen dan kelas kontrol. Penelitian ini menyimpulkan bahwa: 1) peningkatan KMBG mahasiswa yang memperoleh GDL lebih baik dibandingkan dengan mahasiswa yang memperoleh DI; 2) terdapat perbedaan peningkatan KMBG ditinjau dari level Kemampuan Awal Matematika (KAM) mahasiswa; 3) terdapat efek interaksi faktor pembelajaran dan KAM terhadap peningkatan KMBG.

Kata Kunci: Guided Discovery Learning, Pembuktian, Geometri, Mengkonstruksi Bukti Geometri.
\end{abstract}

Abstract. This research aimed to analyze the application of the Guided Discovery Learning (GDL) model in improving the ability to construct geometric proof (KMBG) in Basic Geometry courses. The study used a $3 \times 2$ factorial design experiment involving two Basic Geometry classes with different learning treatments, namely GDL model in the experimental class and the Direct Instruction (DI) model in the control class. The population in this study were all students who took the basic geometry course in the Mathematics Education Study Program at one of University. The research sample of 75 
students was selected by using the Random Sampling Cluster technique, which was divided into experimental and control classes. This study concludes that: 1) the increase in KMBG of students who get GDL was better than students who get DI; 2) there was a difference in the increase in KMBG based on the level of students' initial mathematical ability (KAM); 3) there was an effect of interaction between learning factors and KAM on the increase in $K M B G$.

Keywords: Guided Discovery Learning, Proving, Geometry, Construct Geometric Proof.

\section{Pendahuluan}

Pembelajaran matematika mengalami perubahan dalam konteks perubahan mutu pendidikan sehingga diperoleh hasil pembelajaran yang optimal. Upaya terus dilakukan untuk terwujudnya suatu pembelajaran yang inovatif sesuai dengan perkembangan zaman dan teknologi pendidikan. Perkembangan ilmu pengetahuan dijadikan suatu instrumen dalam mengembangkan pembelajaran matematika, sehingga dapat menentukan kualitas pendidikan. Oleh karena itu, merupakan suatu hal yang logis untuk memperhatikan kualitas pembelajaran matematika.

Kurikulum pendidikan di Indonesia menempatkan geometri pada setiap jenjang pendidikan mulai dari pendidikan dasar hingga pada jenjang pendidikan tinggi. Kurikulum geometri pada pendidikan tinggi setidaknya meliputu geometri datar, geometri ruang, geometri analitik datar dan ruang, serta geometri transformasi. Khusus pada kajian geometri, kurikulum pendidikan tinggi menempatkan geometri sebagai bahan kajian hingga pada sistem aksiomatis menuju pada pembuktian formal. Suatu pembuktian formal geometri akan terbentuk apabila kemampuan mahasiswa dalam menyusun argumentsi geometri berjalan dengan baik hingga pada akhirnya menuliskanya dalam bukti formal. Hal tersebut penting karena Jika seseorang tidak menguasai konsep geometri yang abstrak dan mengungkapkan argumenya dengan baik maka secara otomatis tidak mampu menganalisis untuk mengkonstruksi suatu bukti (Maarif, Wahyudin, Noto, Hidayat, \& Mulyono, 2018).

Pembuktian menjadi indikator utama bagi seorang mahasiswa dalam mengembangkan kematangan bermatematik (Otten, Gilbertson, Males, \& Clark, 2014; Maarif, Perbowo, Noto, \& Harisman, 2019). Sehingga para praktisi di bidang pendidikan matematika mencurahkan pemikiranya untuk melakukan penelitian dalam upaya mengembangkan kemampuan pembuktian bagi para mahasiswa. Pada akhir-akhir ini, penelitian lebih memfokuskan pada bagaimana cara mahasiswa dapat mengkonstruksi bukti dibandingkan dengan kegiatan mahasiswa untuk bagaimana memahami sebuah bukti yang akan dikonstruksi (Hodds, Alcock, \& Inglis 
Loughborough, 2014). Hal tersebut dapat menjadi potensi penyebab kesalahan mahasiswa dalam mengkonstruksi sebuah bukti karena kurang memahami alur pembuktian sesuai dengan sistem aksiomatik.

Untuk mengembangkan kemampuan mengkonstruksi bukti matematis diperlukan sebuah desain pembelajaran yang mempunyai karakteristik membangun katagori, menentukan masalah dan menciptakan lingkungan yang mendukung (Weber, 2005). Menciptakan pembelajaran geometri dalam rangka meningkatkan kemampuan pemahaman geometri, maka pembelajaran harus berpusat pada aktivitas mahasiswa, karena mahasiswa sangat membutuhkan kegiatan aktif dalam proses pembelajaran geometri (Maarif, Wahyudin, Noto, Hidayat, \& Mulyono, 2018). Disamping itu, mahasiswa juga membutuhkan proses penemuan teorema atau sifat-sifat geometri dan memerlukan waktu yang cukup untuk mengeksplorasi serta merefleksikan ide barunya. Sedangkan Heinze \& Reiss (Reiss \& Renkl, 2002) mengungkapkan untuk mengembangkan kemampuan penalaran dan pembuktian matematis diperlukan sebuah pembelajaran yang memberikan kesempatan pada mahasiswa dalam tugas-tugas yang mengarahkan pada penentuan konjektur, eksplorasi terhadap konjektur yang telah dibuat, menjelaskan dan menuliskan bukti secara formal. Kegiatan-kegiatan tersebut dapat dilaksanakan dengan kegiatan diskusi antar kelompok untuk bertukar pikiran ide-ide untuk menentukan kebenaran dari konjektur yang telah dibuat.

Model pembelajaran yang mempunyai karakteristik yang memberikan kesempatan kepada mahasiswa untuk mengeksplorasi ide pemikiranya diantaranya Guided Discovery Learning (GDL). Hal ini didasarkan pada model pembelajaran GDL merupakan sistem dua arah dimana proses pembelajarannya melibatkan mahasiswa dan dosen. Mahasiswa melakukan penemuan (discovery) dan dosen berperan dalam memberikan bimbingan (guided) dengan menganalisis kesulitan dalam memecahkan masalah yang dihadapi oleh mahasiswa (Baroody, Purpura, Eiland, \& Reid, 2015). Selain itu, model GDL adalah model pembelajaran yang mendorong mahasiswa untuk mengajukan suatu pertanyaan, merumuskan jawaban alternatif, dan menyimpulkan prinsip-rinsip umum dari contoh-contoh praktis melalui bimbingan guru atau dosen (Tran, Nguyen, Bui, \& Phan, 2014). Peran pengajar dalam model ini adalah sebagai vasilitator untuk mengarahkan para mahasiswa dalam mengembangkan ide-idenya untuk merumuskan jawaban hingga pada penarikan suatu kesimpulan konsepkonsep matematika yang sedang dipelajari. 
Bicknell-Holmes \& Hoffman (Maarif, 2015) mengambarkan tiga sifat utama GDL yakni: (1) mengeksplorasi dan memecahkan masalah untuk membuat, mengintegrasikan, dan menggeneralisasi pengetahuan; (2) aktivitas-aktivitas berdasar ketertarikan dimana mahasiswa menentukan tahapan dan frekwensi, dan (3) aktivitas-aktivitas yang mendorong integrasi pengetahuan baru kedalam dasar pengetahuan mahasiswa yang telah ada. Pada model GDL struktur pembelajarannya menekankan siswa untuk menemukan polapola, aturan, prinsip, dan struktur matematik melalui eksplorasi terhadap contoh-contoh. Sebagaimana yang dikemukakan Balim bahwa GDL melibatkan suatu urutan induktif, urutan ini dimulai tidak dengan penjelasan sebuah prinsip umum tetapi dengan menghadapkan mahasiswa kepada beberapa contoh dari prinsip, dimana mereka dapat menganalisis, memanipulasi dan bereksperimen (Balim, 2009). Sehingga melalui pembelajaran tersebut mahasiswa dapat mengembangkan kemampuan penalaran dan pembuktian matematis.

Menurut Dyer (Hammer, 1997) terdapat 5 tahapan terurut kegiatan discovery dalam pembelajaran yakni: 1) Association (asosiasi); 2) Questioning (bertanya); 3) Observing (mengamati); 4) Networking (membuat jejaring); dan 5) Experimenting (melakukan percobaan). Pada tahapan questioning, mahasiswa memerlukan bagaimana strategi bertanya yang efektif dalam menjelaskan ide-ide mereka dalam menyusun bukti geometri. Oleh karena itu, untuk membantu mahasiswa mengeksplorasi pengetahuanya dalam membuktikan dan mengoneksikan masalah yang akan dibuktikan, dibuktihkan cara untuk mengontrol proses berpikinya.

Sebagai pembanding dalam penelitian ini, digunakan model Direct Instruction (DI) sebagai kelas kontrol. Pembelajaran pada tingkat perguruan tinggi masih didominasi peranan dosen yang dilakukan dengan pembelajaran langsung (Stockard, Wood, Coughlin, \& Khoury, 2018). Strategi DI adalah model pengajaran yang berpusat pada dosen, dimana pendekatan ini dirancang khusus untuk menunjang proses belajar siswa yang berkaitan dengan pengetahuan deklaratif dan pengetahuan prosedural yang terstruktur dengan baik yang dapat diajarkan dengan pola kegiatan bertahap, selangkah demi selangkah (Flores \& Kaylor, 2000). Sedangkan Carnine (Louden, 2014) mendefinisikan model DI sebagai sebuah pendekatan mengajar yang berorientasi pada keterampilan dan praktek mengajar yang diarahkan oleh guru. Sehingga, pada model DI peran serta dosen dalam perkuliahan sangat dominan. 
Untuk mengeksplorasi kemampuan mengkonstruksi bukti geometri mahasiswa ditentukan seberapa jauh kemampuan awal matematika yang dimilikinya. Pada proses pembelajaran diperkuliahan, sekelompok mahasiswa yang dipilih secara acak akan selalu dijumpai siswa yang memiliki kemampuan tinggi, sedang, dan rendah, hal ini disebabkan kemampuan siswa menyebar secara distribusi normal (Haeruman, Rahayu, \& Ambarwati, 2017). Salah satu prediktor terbaik untuk mengetahui kemampuan matematis adalah perolehan hasil belajar matematika sebelumnya dengan proses penentuan kelompok tinggi, sedang dan rendah (Vilkomir \& O’Donoghue, 2009).

Model GDL biasanya dilakukan dalam kelompok dan bergantung pada pengetahuan awal yang sudah ada. Model pembelajaran ini merupakan model induktif yang membimbing mahasiswa untuk membahas dan mengatur ide nya sendiri. Dosen mengajak mahasiswa untuk memulai diskusi dan untuk berinteraksi dengan mahasiswa lain (Abdisa \& Getinet, 2012). GDL dapat digunakan jika mahasiswa dapat memecahkan masalah baru dari pengetahuan dan pengalaman mereka yang sudah ada. Mahasiswa memiliki latar belakang pengetahuan, teknik dan pemahaman tentang apa yang diharapkan yang dapat dipertimbangkan untuk bimbingan yang lebih efektif.

Ciri utama dari model GDL dalam kegiatan pembelajaran yaitu motivation; data collecting; data processing; closure; dan appraisal (Baroody Purpura, Eiland, \& Reid, 2015). Pada kegiatan pengumpulan data, mahasiswa mengumpulkan lebih dari satu data untuk merangsang pemikiran mahasiswa tentang satu rangkaian pengamatan. Begitupula pada tahapan pemrosesan data yang melibatkan mahasiswa untuk mencoba menarik kesimpulan dari data yang telah dikumpulkan.

Dari pemaparan di atas maka tujuan penelitian ini adalah untuk menganalisis penerapan model GDL dalam meningkatkan kemampuan mengkonstruksi bukti geometri (KMBG) pada perkuliahan geometri dasar.

\section{Metode}

Metode penelitian ini menggunakan factorial design $3 \times 2$ dengan desain penelitian quasi experiment jenis nonequivalent control group design (Sztajn, Wilson, Edgington, Myers, \& Dick, 2013). Sampel penelitian sejumlah 75 mahasiswa dipilih dengan teknik Cluster Random Sampling untuk menentukan satu kelas ekperimen (penerapan model GDL) dan satu kelas kontrol (penerapan model DI). 
Langkah-langkah pembelajaran dengan model GDL yang dilakukan adalah sebagai berikut:

1. Mahasiswa mengeksplorasi masalah-masalah yang disajikan pada lembar kerja pembuktian dengan mengumpulkan data-data seperti informasi yang diketahui dalam masalah yang disajikan untuk membentuk konsep dengan jalan diskusi antar kelompok.

2. Dosen membagi kelompok dengan jumlah kelompok 4-5 mahasiswa.

3. Dosen membagikan Lembar Kerja Mahasiswa (LKM) sesuai dengan tiaptiap pertemuan untuk didiskusikan dan dikerjakan dalam kelompok. Lembar kerja memuat aktivitas ekploratif untuk menemukan pengetahuan baru.

4. Mahasiswa mengeksplorasi masalah-masalah yang disajikan pada LKM dengan mengumpulkan data-data seperti informasi yang diketahui dalam masalah yang disajikan untuk membentuk konsep dengan jalan diskusi antar kelompok (Data Collecting).

5. Mahasiswa berdiskusi mencari solusi dari masalah-masalah yang disajikan (Processing Data).

6. Dosen memantau kerja kelompok mahasiswa dan memberikan bantuan apabila ada mahasiswa yang memerlukan. Pemberian bantuan oleh dosen dilakukan secara cermat, agar tidak mengganggu proses discovery oleh mahasiswa.

7. Dosen memilih hasil pekerjaan salah satu kelompok untuk dibahas secara klasikal. Pembahasan ditekankan melalui penggunaan komunikasi multi arah (dosen-mahasiswa dan antar mahasiswa dengan dosen sebagai fasilitator).

8. Kegiatan akhir perkuliahan dilakukan dengan dosen bersama-sama dengan mahasiswa merangkum pembelajaran secara klasikal (clousure).

9. Dosen melakukan penilain dengan memberikan tes formatif (Appraisal)

10. Kemudian dosen memberikan tugas untuk dikumpulkan pada pertemuan berikutnya.

Adapun data diambil dari data tes kemampuan mengontruksi bukti geometri. Tes kemampuan mengkonstruksi bukti geometri yang digunakan disusun dari indikator: 1) menemukan kesalahan dari langkah bukti yang telah disajikan, kemudian menuliskan kembali bukti yang benar atau valid; 2) Memilih satu dari dua teorema yang sisajikan untuk digunakan dalam membuktikan suatu pernyataan; 3) kemampuan menyusun argumen untuk membuktikan suatu pernyataan (Arnawa, Sumarno, Kartasasmita, \& Baskoro, 2007; Bieda, Ji, Drwencke, \& Picard, 2014). 
Sedangkan, Kemampuan Awal Matematika (KAM) mahasiswa diambil dari dari nilai Ujian Nasional (UN) pada tingkat SMA/Sederajat mahasiswa. Nilai ujian nasional menggmbarkan kemampuan mahasiswa dalam bidang matematika karena diukur dari instrument yang telah dibuat secara nasional oleh pemerintah melalui proses yang sudah terstandarisasi. Peneliti mengambil KAM mahasiswa diambil dari nilai Ujian Nasional (UN) pada tingkat SMA/Sederajat mahasiswa, karena mahasiswa baru pertama kali mengikuti perkuliahan di jenjang universitas dan menggambarkan kemampuan matematis mahasiswa pada semester I (satu).

Untuk memperdalam data, setelah melakukan analisis data statistik dilakukan observasi dan wawancara terhadap 6 responden terkait penerapan model GDL. Responden tersebut terbagi dalam 2 mahasiswa kategori KAM level tinggi, 2 mahasiswa kategori KAM level sedang dan 2 mahasiswa kategori KAM level rendah dengan mengikuti pengkodean seperti terlihat pada tabel 1.

Tabel 1. Pengkodean KAM Mahasiswa

\begin{tabular}{cc}
\hline Kode & Makna Kode \\
\hline R11 & Responden berasal dari kelompok KAM level tinggi, orang yang pertama \\
R12 & Responden berasal dari kelompok KAM level tinggi, orang yang kedua \\
R21 & Responden berasal dari kelompok KAM level sedang, orang yang pertama \\
R22 & Responden berasal dari kelompok KAM level sedang, orang yang kedua \\
R31 & Responden berasal dari kelompok KAM level rendah, orang yang pertama \\
R32 & Responden berasal dari kelompok KAM level rendah, orang yang kedua \\
P & Peneliti \\
\hline
\end{tabular}

Analisis data dilakukan menggunakan analisis Anova dua jalur dengan menganalisis kemampuan mengkonstruksi bukti geometri yang didasarkan KAM mahasiswa. Pengujian hipotesis berkaitan dengan peningkatan kemampuan mengkonstruksi bukti matematis yang terdiri atas: 1) hipotesis 1: terdapat perbedaan peningkatan kemampuan mengkonstruksi bukti geometri antara mahasiswa yang memperoleh pembelajaran menggunakan strategi model GDL dan mahasiswa yang memperoleh pembelajaran dengan model DI; 2) hipotesis 2: terdapat perbedaan peningkatan kemampuan mengkonstruksi bukti geometri antara mahasiswa yang memperoleh pembelajaran menggunakan model GDL dan mahasiswa yang memperoleh pembelajaran menggunakan model DI berdasarkan jenjang KAM mahasiswa. 3) hipotesis 3: terdapat pengaruh interaksi antara strategi GDL dan faktor kemampuan awal mahasiswa terhadap terhadap peningkatan kemampuan mengkonstruksi bukti geometri. 


\section{Hasil dan Pembahasan}

Diperoleh hasil peningkatan Kemampuan Mengkonstruksi Bukti Geometri (KMBG) pada Tabel 2.

Tabel 2. Peningkatan Kemampuan Mengkonstruksi Bukti Geometri Mahasiswa Berdasarkan Level KAM Mahasiswa

\begin{tabular}{|c|c|c|c|c|c|c|c|}
\hline \multirow{2}{*}{$\begin{array}{c}\text { Kategori } \\
\text { KAM }\end{array}$} & \multirow[t]{2}{*}{ Pemb. } & \multirow[t]{2}{*}{$\mathrm{N}$} & \multirow[t]{2}{*}{ Data } & \multicolumn{2}{|c|}{ Skor } & \multirow{2}{*}{$\begin{array}{l}\text { Rata- } \\
\text { rata }\end{array}$} & \multirow{2}{*}{$\begin{array}{c}\text { Simpangan } \\
\text { Baku }\end{array}$} \\
\hline & & & & Min. & Maks. & & \\
\hline \multirow[t]{6}{*}{ Tinggi } & \multirow[t]{3}{*}{ GDL } & \multirow[t]{3}{*}{6} & Pretes & 1 & 6 & 3,33 & 2,066 \\
\hline & & & Postes & 8 & 13 & 10,33 & 2,066 \\
\hline & & & n-Gain & 0,333 & 0,727 & 0,557 & 0,137 \\
\hline & \multirow[t]{3}{*}{ DI } & \multirow[t]{3}{*}{5} & Pretes & 1 & 6 & 3,80 & 1,789 \\
\hline & & & Postes & 4 & 11 & 7,60 & 2,702 \\
\hline & & & n-Gain & 0,000 & 0,583 & 0,307 & 0,221 \\
\hline \multirow[t]{6}{*}{ Sedang } & \multirow[t]{3}{*}{ GDL } & \multirow[t]{3}{*}{23} & Pretes & 0 & 7 & 3,52 & 1,997 \\
\hline & & & Postes & 4 & 12 & 7,83 & 2,570 \\
\hline & & & n-Gain & 0,000 & 0,733 & 0,334 & 0,226 \\
\hline & \multirow[t]{3}{*}{ DI } & \multirow[t]{3}{*}{23} & Pretes & 0 & 7 & 2,35 & 1,824 \\
\hline & & & Postes & 1 & 8 & 5,13 & 1,890 \\
\hline & & & n-Gain & 0,000 & 0,500 & 0,194 & 0,151 \\
\hline \multirow[t]{6}{*}{ Rendah } & \multirow[t]{3}{*}{ GDL } & \multirow[t]{3}{*}{6} & Pretes & 0 & 2 & 1,33 & 0,816 \\
\hline & & & Postes & 7 & 10 & 8,17 & 1,169 \\
\hline & & & n-Gain & 0,357 & 0,600 & 0,464 & 0,087 \\
\hline & \multirow[t]{3}{*}{ DI } & \multirow[t]{3}{*}{7} & Pretes & 0 & 5 & 2,14 & 1,574 \\
\hline & & & Postes & 2 & 7 & 4,29 & 1,799 \\
\hline & & & n-Gain & 0,000 & 0,357 & 0,147 & 0,149 \\
\hline \multirow{6}{*}{$\begin{array}{l}\text { Keseluru- } \\
\text { han }\end{array}$} & \multirow[t]{3}{*}{ GDL } & \multirow[t]{3}{*}{35} & Pretes & 0 & 7 & 3,06 & 2,028 \\
\hline & & & Postes & 4 & 13 & 8,31 & 2,447 \\
\hline & & & n-Gain & 0,000 & 0,733 & 0,394 & 0,212 \\
\hline & \multirow[t]{3}{*}{ DI } & \multirow[t]{3}{*}{35} & Pretes & 0 & 7 & 2,51 & 1,805 \\
\hline & & & Postes & 1 & 11 & 5,31 & 2,180 \\
\hline & & & n-Gain & 0,000 & 0,583 & 0,201 & 0,163 \\
\hline
\end{tabular}

Tabel 2 menunjukan bahwa KMBG mahasiswa dengan level KAM tinggi, sedang dan rendah, dimana pembelajarannya menggunakan GDL mengalami peningkatan KMBG lebih tinggi dari pada mahasiswa yang pembelajarannya mengunakan DI. Begitu juga dengan nilai gain secara keseluruhan, KMBG mahasiswa yang pembelajarannya menggunakan GDL mengalami peningkatan KMBG lebih tinggi dari pada mahasiswa yang pembelajarannya mengunakan DI.

Data pada Tabel 2 kemudian dianalisis mengunakan Software SPSS untuk menguji ketiga hipotesis yang telah disebutkan. Adapun uji yang digunakan yaitu uji Anova Dua Jalur. Berdasarkan skor peningkatan kemampuan pembuktian matematis diperoleh hasil pengujian seperti tampak pada Tabel 3. 
Tabel 3. Hasil Uji Anova Dua Jalur Skor Peningkatan Kemampuan Pembuktian Matematis Mahasiswa Berdasarkan Faktor Pembelajaran dan Level KAM Mahasiswa

\begin{tabular}{cccccc}
\hline Source & $\begin{array}{c}\text { Type III Sum of } \\
\text { Squares }\end{array}$ & Df & $\begin{array}{c}\text { Mean } \\
\text { Square }\end{array}$ & F & Sig. \\
\hline Corrected Model & $386,673^{\mathrm{a}}$ & 5 & 77,335 & 8,893 &, 000 \\
Intercept & 1755,986 & 1 & 1755,986 & 201,936 &, 000 \\
Pembelajaran & 54,775 & 1 & 54,775 & 6,299 &, 015 \\
KAM & 101,474 & 2 & 50,737 & 5,835 &, 005 \\
Pembelajaran * KAM & 68,677 & 2 & 34,339 & 3,949 &, 024 \\
Error & 556,527 & 64 & 8,696 & & \\
Total & 3634,000 & 70 & & & \\
Corrected Total & 943,200 & 69 & & & \\
\hline
\end{tabular}

Dari hasil pengujian Anova Dua Jalur pada Tabel 3 dapat diketahui bahwa: (a) nilai sig. pada baris "Model" adalah 0,015 dan nilai ini lebih kecil dari 0,05 dengan taraf signifikan $\alpha=0,05$, maka hipotesis penelitian yang menyatakan terdapat perbedaan peningkatan mengkonstruksi bukti geometri antara mahasiswa yang memperoleh pembelajaran menggunakan GDL dan mahasiswa yang memperoleh pembelajaran menggunakan model DI diterima; (b) nilai sig. pada baris "KAM" adalah 0,005 dan nilai ini lebih kecil dari 0,05 dengan taraf signifikan $\alpha=0,05$, maka hipotesis penelitian yang menyatakan terdapat perbedaan peningkatan kemampuan pembuktian matematis antara mahasiswa yang memperoleh pembelajaran menggunakan model GDL pembelajaran menggunakan model DI berdasarkan jenjang kemampuan awal matematis (KAM) mahasiswa diterima.

Untuk mengetahui kelompok mahasiswa dengan level KAM mana yang berbeda, dilanjutkan dengan uji HSD Tukey dengan hasil perhitungan seperti terlihat pada Tabel 4 .

Tabel 4. Hasil Uji HSD Tukey

\begin{tabular}{ccccccc}
\hline \multirow{2}{*}{ (I) KAM } & Mean & & \multicolumn{3}{c}{$95 \%$ Confidence } \\
& (J) KAM & $\begin{array}{c}\text { Difference } \\
\text { (I-J) }\end{array}$ & Etd. & Sig. & \multicolumn{2}{c}{ Interval } \\
& & & & Lower & Upper \\
Bound & Bound \\
\hline \multirow{2}{*}{ Tinggi } & Sedang & 1,59 &, 990 &, 252 &,- 79 & 3,96 \\
& Rendah & $4,08^{*}$ & 1,208 &, 004 & 1,18 & 6,98 \\
& Tinggi & $-1,59$ &, 990 &, 252 & $-3,96$ &, 79 \\
\multirow{2}{*}{ Redang } & Rendah & $2,49^{*}$ &, 926 &, 024 &, 27 & 4,71 \\
& Tinggi & $-4,08^{*}$ & 1,208 &, 004 & $-6,98$ & $-1,18$ \\
& Sedang & $-2,49^{*}$ &, 926 &, 024 & $-4,71$ &,- 27 \\
\hline
\end{tabular}


Berdasarkan Tabel 4 dapat disimpulkan bahwa terdapat perbedaan yang signifikan antara peningkatan kemampuan pembuktian matematis pada kelompok mahasiswa level KAM mahasiswa tinggi dan sedang pada signifikan $\alpha=0,05$. Hasil ini menunjukkan bahwa terdapat perbedaan yang signifikan pada level KAM terhadap peningkatan kemampuan mengkonstruksi bukti geometri mahasiswa.

Tabel 3 juga menunjukan bahwa nilai sig. pada baris "Model*KAM" adalah 0,024 dan nilai ini kurang dari dari 0,05 dengan taraf signifikan $\alpha=0,05$, maka terdapat pengaruh interaksi antara model GDL dan faktor KAM mahasiswa terhadap peningkatan kemampuan mengkonstruksi bukti geometri.

Hasil uji statistik menunjukkan peningkatan kemampuan mengkonstruksi bukti geometri mahasiswa kelas ekperimen secara keseluruhan lebih baik dibandingkan dengan mahasiswa kelas kontrol secara keseluruhan. Hal tersebut juga berlaku pada kategori KAM, meskipun hanya pada kategori tinggi dan sedang. Temuan tersebut juga didukung oleh hasil analisis uji pengaruh interaksi antara faktor pembelajaran dan KAM yang menunjukkan bahwa bahwa faktor pembelajaran memberikan pengaruh positif peningkatan kemampuan pembuktian matematis mahasiswa di kategori KAM. Hal tersebut menunjukkan bahwa model GDL mempunyai pengaruh yang baik terhadap peningkatan kemampuan mengkonstruksi bukti geometri mahasiswa pada mata kuliah Geometri Dasar. Yuliana, Tasari, \& Wijayanti (2017) menyatakan bahwa model GDL lebih efektif digunakan dalam pembelajaran matematika dibandingkan model pembelajaran konvensional. Selain itu, proses penyelesaian masalah siswa yang mengalami pembelajaran menggunakan model GDL lebih baik dan bervariasi dibandingkan dengan pembelajaran konvensional (Yuliani \& Saragih, 2015).

Pembelajaran dengan model GDL diterapakan dalam perkuliahan geometri dasar selama setengah semester. Analisis terhadap pembelajaran dilakukan untuk mengetahui sejauh mana dukungan implementasi dari pelaksanaan GDL dengan melakukan wawancara terhadap responden (enam mahasiswa).

Dari hasil wawancara yang telah dilakukan ditemukan beberapa fakta sebagai berikut. Pemahaman terhadap pembuktian materi geometri dasar dilakukan dengan kegiatan eksplorasi terhadap teorema dan masalah pembuktian yang disajikan dalam tiap pembelajaran menggunakan model GDL. Hasil wawancara yang telah dilakukan terhadap keenam responden 
terhadap pelaksanaan perkuliahan dengan menngunakan model GDL mengungkapkan bahwa pembelajaran yang telah dilaksanakan memberikan kemudahan dalam memahami materi geometri dasar yang diajarkan. Berikut disajian bagian kutipan wawancara terhadap responden.

$\begin{array}{ll}\text { P... } & \text { Oke..kan kemaren sudah diterapkan model GDL dalam pembelajaran geometri, } \\ & \text { apakah pada mata kuliah lain ada yang menerapkan pembelajaran seperti ini pada } \\ & \text { mata kuliah lain? } \\ \mathrm{R} 12 & \text { Sebennarnya sudah ada tapi tidak rutin tiap minggunya cuman satu kali pertemuan } \\ & \text { saja. } \\ \mathrm{P} & \text { Ada bedanya tidak? } \\ \mathrm{R} 12 & \text { Banyak bedanya pak, kalo pada mata kuliah lain tidak ada presentasi, dan itu juga } \\ & \text { diskusi kelompok cuman satu pertemuan saja. Trus kalau pada mata kuliah lain } \\ & \text { materi minggu lalu tidak disinggung sedangkan pada pembelajaran kemaren [model } \\ & \text { GDL] sebelum memulai materi baru bapak menyinggung sedikit materi minggu } \\ & \text { yang lalu. } \\ & \text { Apakah model pembelajaran yang kita terapkan kemaren [model GDL] apakah } \\ & \text { efektif? } \\ \mathrm{R} 12 & \text { Menurut saya efektif pak } \\ \mathrm{P} & \text { Efektifnya dimana? } \\ \mathrm{R} 12 & \text { Jadi lebih paham pak materinya karena ada bantuan LKM, terus kita bisa } \\ & \text { mengungkapkan ide di kelompoknya }\end{array}$

Kutipan wawancara di atas terhadap ketiga responden yang di wawancarai menunjukan bahwa ketiganya merasa pembelajaran yang dilakukan lebih efektif dibandingkan pembelajaran yang biasa dilakukan sebelumnya (pembelajaran pada perkulian lain yang dialaminya). Mahasiswa yang termasuk dalam kategori tinggi yaitu R12 mengungkapkan bahwa pembelajaran yang telah dilakukan (pembelajaran menggunakan model GDL) berbeda dengan pembelajaran pada mata kuliah lain. Alasan R12 mengungkapkan bahwa pada pembelajaran pada mata kuliah lain tidak ada kegiatan presentasi dan diskusi kelompok hanya satu pertemuan saja. Mahasiswa R12 juga mengungkapkan pada pembelajaran mata kuliah lain pada setiap pertemuan tidak menyinggung materi sebelumnya sebagai bahan apersepsi. Sedangakan pada pembelajaran menggunakan model GDL dengan terdapat kegiatan presentasi, diskusi dan setiap pertemuan menyinggung materi-materi sebelumnya, sehingga menurut R12 pembelajaran lebih efektif dan materi lebih mudah dipahami dengan adanya LKM yang telah diberikan. Hal ini sejalan dengan hasil penelitian (Imawan, 2015; Kartikaningtyas \& Kusmayadi, 2017; Khasanah, Usodo, \& Subanti, 2018) yang menunjukan bahwa GDL dinilai efektif dalam pembelajaran geometri. 
Kegiatan penemuan dalam model GDL merupakan prinsip utama dari model tersebut. Kegiatan penemuan yang dipandu dengan menggunakan LKM sebagai guided membuat peran serta mahasiswa dalam pembelajaran lebih aktif dalam menyelesaikan masalah-masalah yang disajikan sehingga pada suatu kesimpulan. Strategi-strategi yang dilakukan dalam menyelesaikan masalah dilakukan oleh mahasiswa dalam proses penemuan suatu jawaban atau kesimpulan akhir. Hasil proses wawancara menunjukan bahwa mahasiswa lebih aktif dalam menyelesaikan permasalahan yang disajikan dan mencoba menerapkan berbagai macam strategi pada proses penemuan. Berikut kutipan bagian wawancara yang telajh dilakukan.

P Ketika menghadapi masalah seperti ini [masalah yang ada di LKM], apa langkahlangkah yang dilakukan R11 [menyebutkan nama responden]?

R11 Langkah-langkahnya yang pertama membaca soal, menggambar sketsa diagram.

P Selanjutnya..

R11 Kita cari informasi yang sudah diketahui.

P Selanjutnya...

R11 Mencari hubungan dengan langkah-langkah yang kita kerjakan. Ada hubungan apa dengan langkah-langkah sebelumnya.

P Untuk menghubungkan langkah-langkah yang sudah dikerjakan, apa yang R11 [menyebutkan nama responden] berpikirnya seperti apa?

R11 Menghubungkan konsep yang dekat pak. misalkan yang ada di masalah ini kan diketahui di situ terkait sudut dalam berseberangan berarti saya akan menghubungkan dengan sudut-sudut yang lain seperti sudut sehadap, sudut dalam sepihak dan yang lain-lain pokoknya masih dalam lingkup situ pak.

$\mathrm{P} \quad J a d i$ mngaitkan teorema-teorema yang sudah ada yah.

R11 [mengangguk].

Kutipan bagian wawancara dengan mahasiswa menunjukan bahwa kegiatan penemuan yang dilakukan menggunakan LKM lebih efektif untuk memahami materi yang diajarkan dengan mencari strategi-strategi penyelesaian masalah. Mahasiswa R11 mengungkapkan dalam menyelesaikan masalah yang disediakan dalam menemukan jawaban yaitu dengan membaca masalah, mensketsakan gambar, mencari informasi yang diketahui dan menghubungkan teorema-teorema yang terkait. Terlihat bahwa menurut mahasiswa R11 aktif dalam menemukan jawaban dari masalah yang disediakan di LKM dengan pertanyaan-pertanyaan bantuan sebagai guided. Pada proses penemuan jawaban dituntun oleh pertanyaanpertanyaan untuk menarik suatu kesimpulan, sehingga lebih semangat dan memahami konsep yang sedang diajarkan. 
Proses diskusi dalam pembelajaran model GDL menjadikan mahasiswa lebih aktif dalam mengungkapkan ide dan argumenya dalam menyelesaikan masalah-masalah yang disajikan. Proses penemuan dalam pembelajaran dialakukan dengan diskusi kelompok dengan LKM sebagai bahan diskusi. Proses diskusi yang dilakukan dalam pembelajaran memberikan kesan yang sangat baik bagi mahasiswa. Hal tersebut terlihat dari kutipan bagian wawancara yang memberikan gambaran mahasiswa terhadap proses diskusi berikut.

P Menurut R31, bagaimana perkuliahan yang kita lakukan kemarin [model GDL]?

R31 Menyenangkan pak

$P \quad$ Menyenangkannya dalam hal apa?

R31 Ya bisa berdiskusi dengan teman, terus itu apa namanya bisa mengenal karakter teman lain. Kan kita baru semester awal kan, jadi kita bisa mengenal teman-teman lebih dekat dengan pembelajaran seperti yang kemarin kita lakukan

$P \quad$ Jadi, dapat saling sharing yah.

R31 Iyah pak

Proses diskusi menjadi tempat untuk saling sharing pengetahuan dan mengungkapkan ide argumentasinya dalam menyelesaikan permasalahn yang disediakan dalam LKM. Mahasiswa R31 mengungkapkan proses diskusi sangata membantu dalam proses pembelajaran karena dalam satu kelompok terdapat anggota kelompok yang cepat memahami materi di LKM da nada anggota kelompok yang kurang cepat dalam memahami materi. GDL merangsang kreatifitas siswa dalam membangun pengetahuan yang baru (Asri \& Noer, 2015). Jadi proses sharing pengetahuan dalam proses diskusi sangat membantu dimana anggota kelompok yang paham memberi tahu anggota kelompok yang kurang memahami materi atau penyelesaian masalah yang disajikan dalam LKM. Selain itu, terdapat peningkatan motivasi belajar melalui model pembelajaran GDL.

Proses diskusi juga dijadikan sebagai proses saling mengenal satu sama lain karakteristik dari tiap-tiap anggota kelompok. Hal tersebut yang diungkapkan oleh mahasiswa R31, sehingga dalam proses diskusi tidak ada gap (batasan) dalam mengungkapkan argumentasinya. Dengan saling mengenal maka proses sharing pengetahuan dapat berjalan dengan lancar karena proses keakraban yang telah dibangun dalam diskusi keompok dan sangat menyenangkan dalam kegiatan pembelajaran.

Setelah berdiskusi dan menyimpulkan hasil pekerjaan tiap-tiap kelompok, mahasiswa memperesentasikan hasil kerjanya di depan kelas. Proses 
presentasi pada model GDL bertujuan untuk menyamakan persepsi secara klasikal dari kesimpulan tiap-tiap kelompok. Mahasiswa merasa kegiatan presentasi sangat membantu dalam proses pembelajaran. Hal tersebut terlihat dari kutipan bagian wawancara dengan mahasiswa R12 sebagai berikut.

$\begin{array}{ll}\text {... } & \text {... } \\ \mathrm{P} & \text { Oke.. kan kemaren sudah diterapkan model GDL dalam pembelajaran geometri, } \\ & \text { apakah pada mata kuliah lain ada yang menerapkan pembelajaran seperti ini pada } \\ & \text { mata kuliah lain? } \\ \text { R12 } & \text { Sebenarnya sudah ada tapi tidak rutin tiap minggunya cuman satu kali pertemuan } \\ & \text { saja. } \\ \text { P } & \text { Ada bedanya tidak? } \\ \text { R12 } & \text { Banyak bedanya pak, kalo pada mata kuliah lain tidak ada presentasi, dan itu juga } \\ & \text { diskusi kelompok cuman satu pertemuan saja. Trus kalau pada mata kuliah lain } \\ & \text { materi minggu lalu tidak disinggung sedangkan pada pembelajaran kemarin [model } \\ & \text { GDL] sebelum memulai materi baru bapak menyinggung sedikit materi minggu } \\ & \text { yang lalu. }\end{array}$

Dari kutipan bagian wawancara di atas terlihat bahwa kegiatan pembelajaran manggunakan model GDL lebih efektif karena adanya kegitan presentasi. Mahasiswa R12 mengungkapkan bahwa kegiatan proses pembelajaran yang telah dilakukan efektif karena adanya kegitan presentasi di depan kelas. Mahasiswa R12 juga mengungkapkan bahwa pada perkuliahan di mata kuliah lain tidak ada kegiatan presentasi di depan kelas, sehingga dengan adanya kegiatan presentasi menjadikan pembelajaran berbeda dengan mata kuliah-mata kulliah yang lainya. Respon ini sejalan dengan hasil penelitian Parno (2015) yang menunjukan bahwa model GDL dapat meningkatkan hasil belajar siswa.

\section{Simpulan}

Bedasarkan hasil penelitian disimpulkan bahwa: 1) peningkatan KMBG mahasiswa yang memperoleh model GDL lebih baik dibandingkan dengan mahasiswa yang memperoleh model $D I ; 2$ ) terdapat perbedaan peningkatan kemampuan mengkonstruksi bukti geometri ditinjau dari level KAM mahasiswa; 3) terdapat efek interaksi faktor pembelajaran dan KAM mahasiswa terhadap peningkatan kemampuan mengontrukti bukti geometri. Berdasarkan kesimpulan tersebut, dapat dikatakan bahwa model GDL sangat efektif diterapkan dalam proses pembelajaran geometri khususnya pada proses mengkonstruksi bukti geometri. Model GDL hendaknya dapat menjadi alternatif pengembangan pembelajaran, khususnya pembelajaran geometri ditingkat perguruan tinggi. Kegiatan pada proses pembelajaran 
menggunakan model GDL mengaktifkan mahasiswa dalam penyelesain tugas-tugas analisis yang diberikan dapat mengembangkan kemampuan mengkonstruksi bukti geometri.

\section{Ucapan Terima Kasih}

Pendanaan untuk penelitian ini disediakan oleh Penelitian dan Pengembangan Universitas Muhammadiyah Prof. DR. HAMKA dan Universitas Swadaya Gunung Djati. Kami ingin mengucapkan terima kasih kepada mahasiswa Program Pendidikan Matematika Universitas PGRI Semarang atas partisipasi dan kontribusinya.

\section{Daftar Pustaka}

Abdisa, G., \& Getinet, T. (2012). The Effect of Guided Discovery on Students'. Physics Achievement. Journal Physic Education, 6(4), 530-537.

Arnawa, I. M., Sumarno, U., Kartasasmita, B., \& Baskoro, E. T. (2007). Applying the Apos Theory To Improve Students Ability To Prove in Elementary Abstract Algebra. Journal of the Indonesian Mathematical Society, 13(1), 133-148.

Asri, E. Y., \& Noer, S. H. (2015). Guided Discovery Learning dalam Pembelajaran Matematika. In Prosiding Seminar Nasional Matematika dan Pendidikan Matematika, 891-896.

Balim, A. G. (2009). The Effects of Discovery Learning on Students' Success and Inquiry Learning Skills. Eurasian Journal of Educational Research, 35(35), 1-20.

Baroody, A. J., Purpura, D. J., Eiland, M. D., \& Reid, E. E. (2015). The Impact of Highly and Minimally Guided Discovery Instruction on Promoting The Learning of Reasoning Strategies for Basic Add-1 and Doubles Combinations. Early Childhood Research Quarterly, 30(PA), 93-105.

Bieda, K. N., Ji, X., Drwencke, J., \& Picard, A. (2014). Reasoning-and-Proving Opportunities in Elementary Mathematics Textbooks. International Journal of Educational Research, 64, 71-80.

Flores, M. M., \& Kaylor, M. (2000). The effects of a Direct Instruction Program on The Fraction Performance of Middle School Students At-Risk For Failure In Mathematics. Journal of Instructional Psychology, 34(2), 84-94.

Haeruman, L. D., Rahayu, W., \& Ambarwati, L. (2017). Pengaruh Model Discovery Learning Terhadap Peningkatan Kemampuan Berpikir Kritis Matematis Dan Self-Confidence Ditinjau Dari KAM Siswa Sma Di Bogor Timur. Jurnal Penelitian Dan Pembelajaran Matematika, 10(2), 157-168.

Hammer, D. (1997). Discovery learning and discovery teaching. Cognition and Instruction, 15(4), 485-523.

Hodds, M., Alcock, L., \& Inglis Loughborough, M. (2014). Self-explanation training improves proof comprehension. Journal for Research in Mathematics Education, 45(1), 62-101.

Imawan, O. R. (2015). Perbandingan Antara Keefektifan Model Guided Discovery Learning dan Project-Based Learning Pada Matakuliah Geometri. PYTHAGORAS: Jurnal Pendidikan Matematika, 10(2), 179-188.

Kartikaningtyas, V., \& Kusmayadi, T. A. (2017). Contextual Approach with Guided Discovery Learning and Brain Based Learning in Geometry Learning. Journal of Physics: Conference Series, 895(1), 012024.

Khasanah, V. N., Usodo, B., \& Subanti, S. (2018). Guided Discovery Learning In Geometry Learning. Journal of Physics: Conference Series, 983(1), 012160. 
Louden, B. (2014). Direct instruction and the teaching of early reading. In The Conversation.

Maarif, S. (2015). Improving Junior High School Students' Mathematical Analogical Ability Using Discovery Learning Method. International Journal of Research in Education and Science, 2(1), 114.

Maarif, S, Perbowo, K. S., Noto, M. S., \& Harisman, Y. (2019). Obstacles in Constructing Geometrical Proofs of Mathematics-Teacher-Students Based on Boero's Proving Model. Journal of Physics: Conference Series, 1315, 012043.

Maarif, S., Wahyudin, W., Noto, M. S., Hidayat, W., \& Mulyono, H. (2018). Geometry Exploration Activities Assisted With Dynamic Geometry Software (DGS) in a Teacher Education Classroom. Infinity Journal, 7(2), 133-146.

Otten, S., Gilbertson, N. J., Males, L. M., \& Clark, D. L. (2014). The Mathematical Nature of Reasoning-and-Proving Opportunities in Geometry Textbooks. Mathematical Thinking and Learning, 16(1), 51-79.

Parno, P. (2015). Pengaruh Model Penemuan Terbimbing Dengan Strategi Self-Explanation Terhadap Prestasi Belajar Fisika Zat Padat Mahasiswa. Jurnal Pendidikan Fisika Indonesia, 11(1), 23-35.

Reiss, K., \& Renkl, A. (2002). Learning to prove: The Idea of Heuristic Examples. ZDM International Journal on Mathematics Education, 34(1), 29-35.

Stockard, J., Wood, T. W., Coughlin, C., \& Khoury, C. R. (2018). The Effectiveness of Direct Instruction Curricula: A Meta-Analysis of a Half Century of Research. Review of Educational Research, 88(4), 479-507.

Sztajn, P., Wilson, H., Edgington, C., Myers, M., \& Dick, L. (2013). Using Design Experiments to Conduct Research on Mathematics Professional Development. Alexandria: Revista de Educação Em Ciência e Tecnologia, 6(1), 9-34.

Tran, T., Nguyen, N.-G., Bui, M.-D., \& Phan, A.-H. (2014). Discovery Learning with the Help of the GeoGebra Dynamic Geometry Software. International Journal of Learning, Teaching and Educational Research, 7(1), 44-57.

Vilkomir, T., \& O'Donoghue, J. (2009). Using Components of Mathematical Ability for Initial Development and Identification of Mathematically Promising Students. International Journal of Mathematical Education in Science and Technology, 40(2), 183-199.

Weber, K. (2005). Problem-Solving, Proving, and Learning: The Relationship Between Problem-Solving Processes and Learning Opportunities in The Activity of Proof Construction. Journal of Mathematical Behavior, 24(3-4), 351-360.

Yuliana, Y., Tasari, T., \& Wijayanti, S. (2017). The Effectiveness Of Guided Discovery Learning To Teach Integral Calculus For The Mathematics Students Of Mathematics Education Widya Dharma University. Infinity Journal, 6(1), 01-10.

Yuliani, K., \& Saragih, S. (2015). The Development of Learning Devices Based Guided Discovery Model to Improve Understanding Concept and Critical Thinking Mathematically Ability of Students at Islamic Junior High School of Medan. Journal of Education and Practice, 6(24), 116-128. 